\title{
Thrombotic events following tocilizumab therapy in critically ill COVID-19 patients: a Façade for prognostic markers
}

Bassam Atallah ${ }^{1,2^{*}}$, Wasim El Nekidy ${ }^{1,2}$, Saad I. Mallah ${ }^{3}$, Antoine Cherfan ${ }^{1}$, Laila AbdelWareth ${ }^{4}$, Jihad Mallat ${ }^{2,5,6}$ and Fadi Hamed ${ }^{5}$

\begin{abstract}
Background: Hospitals in the Middle East Gulf region have experienced an influx of COVID-19 patients to their medical wards and intensive care units. The hypercoagulability of these patients has been widely reported on a global scale. However, many of the experimental treatments used to manage the various complications of COVID19 have not been widely studied in this context. The effect of the current treatment protocols on patients' diagnostic and prognostic biomarkers may thus impact the validity of the algorithms adopted.

Case presentation: In this case series, we report four cases of venous thromboembolism and 1 case of arterial thrombotic event, in patients treated with standard or intensified prophylactic doses of unfractionated heparin or low molecular weight heparin at our institution. Tocilizumab has been utilized as an add-on therapy to the standard of care to treat patients with SARS-CoV-2 associated acute respiratory distress syndrome, in order to dampen the hyperinflammatory response. It is imperative to be aware that this drug may be masking the inflammatory markers (e.g. IL6, CRP, fibrinogen, and ferritin), without reducing the risk of thrombotic events in this population, creating instead a façade of an improved prognostic outcome. However, the D-dimer levels remained prognostically reliable in these cases, as they were not affected by the drug and continued to be at the highest level until event occurrence.

Conclusions: In the setting of tocilizumab therapy, traditional prognostic markers of worsening infection and inflammation, and thus potential risk of acute thrombosis, should be weighed carefully as they may not be reliable for prognosis and may create a façade of an improved prognostic outcome instead. Additionally, the fact that thrombotic events continued to be observed despite decrease in inflammatory markers and the proactive anticoagulative approach adopted, raises more questions about the coagulative mechanisms at play in COVID-19, and the appropriate management strategy.
\end{abstract}

Keywords: COVID-19, Tocilizumab, Thrombosis, D-dimers, Prognostic markers

\footnotetext{
* Correspondence: Atallab@clevelandclinicabudhabi.ae

'Department of Pharmacy Services, Cleveland Clinic Abu Dhabi, Al Maryah Island, Abu Dhabi, United Arab Emirates

${ }^{2}$ Cleveland Clinic Lerner College of Medicine of Case Western Reserve University, Cleveland, OH, USA

Full list of author information is available at the end of the article
}

(c) The Author(s). 2020 Open Access This article is licensed under a Creative Commons Attribution 4.0 International License, which permits use, sharing, adaptation, distribution and reproduction in any medium or format, as long as you give appropriate credit to the original author(s) and the source, provide a link to the Creative Commons licence, and indicate if changes were made. The images or other third party material in this article are included in the article's Creative Commons licence, unless indicated otherwise in a credit line to the material. If material is not included in the article's Creative Commons licence and your intended use is not permitted by statutory regulation or exceeds the permitted use, you will need to obtain permission directly from the copyright holder. To view a copy of this licence, visit http://creativecommons.org/licenses/by/4.0/. The Creative Commons Public Domain Dedication waiver (http://creativecommons.org/publicdomain/zero/1.0/) applies to the data made available in this article, unless otherwise stated in a credit line to the data. 


\section{Background}

The COVID-19 (SARS CoV-2) pandemic has stricken all corners of the globe. Hospitals in the Middle East Gulf region, including the United Arab Emirates (UAE), have experienced an influx of coronavirus patients to their medical wards and intensive care units. With over 62, 000 confirmed SARS-CoV-2 cases to date in the UAE [1], and a diverse population composed of locals and expatriates, it is expected that the various reported manifestations of the pandemic are to be observed in this country as well. Our quaternary care hospital has adapted to accommodate the influx by approximately doubling ICU bed capacity, and dedicating half of it for COVID-19 patients.

Coagulopathies of controversial mechanisms and etiologies have been widely reported in COVID-19 patients $[2,3]$. Additionally, treatment approaches vary by institution, with many of the drugs being used in unique contexts and unchartered territory. As a result, devised algorithms for risk assessment, management, and prognosis may be based on markers atypically impacted by the adopted treatment regimens of novel COVID-19 patients.

\section{Case presentation}

We report four cases of venous thromboembolism (VTE) and 1 case of arterial thrombotic event, in patients treated with standard or intensified prophylactic doses of unfractionated heparin or low molecular weight heparin at our institution. One patient experienced a second pulmonary embolism while on therapeutic intravenous heparin with an activated partial thromboplastin time (aPTT) goal of 60 to $85 \mathrm{~s}$ following a first VTE event. All patients were admitted to the ICU for SARSCoV-2 infection. All five patients received tocilizumab prior to the thrombotic events.

Patient 1 is a 51-year-old male who received tocilizumab prior to transfer to our hospital. His D-dimer was over 6 times the upper limit of normal (ULN) and started on intensified prophylaxis with unfractionated heparin infusion (UFH) 7500 units TID per our COVID anticoagulation protocol [4]. His C-reactive protein (CRP) and fibrinogen were within normal limits, while ferritin and IL- 6 were both elevated. On day 3 of admission, ischemia of the first 3 toes was noted with no capillary refill, and no pulse on bedside ultrasound (US). Patient anticoagulation plan was changed to heparin DVT/PE protocol (aPTT 60-85 s). CT angiogram showed partially detaching/floating thrombi noted $4 \mathrm{~cm}$ infrarenal abdominal aorta, compromising the lumen and leading to acute limb ischemia with extensive abdominal and bilateral lower extremity thrombus. Ddimer was still over 6 times ULN while all other markers were lower than at admission. Patient was screened for lupus anticoagulant (LAC), and returned negative. Patient developed secondary ischemia of bilateral lower extremity developing left foot dry gangrene requiring below-knee amputation. Patient eventually improved and was discharged on day 75 of admission on oral anticoagulation.

Patient 2, a 79-year-old male, showed no acute or chronic pulmonary embolism (PE) on CT chest with PE protocol at admission. CRP was elevated and D-dimer was over 6 times the upper limit of normal. He received DVT prophylaxis with Enoxaparin $40 \mathrm{mg}$ subcutaneously (SC) daily. On Day 3 of admission, tocilizumab $400 \mathrm{mg}$ intravenously was administered. Patient remained critically ill and on mechanical ventilation, having failed weaning trials. Two weeks into admission, he had a sudden increase in $\mathrm{O} 2$ requirement, which was contributed to by secondary bacterial infection. However, given prolonged ICU course and known COVID-19 status, DVT US of lower extremities was performed. DVT in bilateral calf veins was evident, and patient was started on full anticoagulation using unfractionated heparin infusion. His D-dimer was $>4$ ULN at that time while CRP and ferritin were elevated, but much lower than admission. Almost 30 days post ICU admission, he suddenly went into Pulseless Electrical Activity rhythm. Bedside focused ICU ECHO showed very subtle cardiac motion, no pericardial effusion, no carotid or femoral arteries pulsation, and with evidence of large clot in the right atrium, likely representing massive PE. As patient was already on comfort care measures, tissue plasminogen activator was not given and patient was pronounced dead. Patient was not screened for lupus anticoagulant.

Patient 3 is a 31 -year-old male, with thalassemia trait and mild intermittent asthma, admitted with flulike symptoms. Patient was hypoxemic on presentation, and was transferred to the ICU with SPO2 in the 80s requiring nonrebreather oxygen mask. CXR showed pulmonary infiltrates. COVID-19 RT-PCR test was positive from day 1 , and patient received tocilizumab on same day. Biomarkers on admission showed a D-dimer elevation of 3 times ULN. Patient was placed on standard dose DVT prophylaxis with low molecular weight heparin. A point of care US performed on day 7 in response to bilateral lower limb pain and D-dimer elevation to over 6 times ULN revealed occlusive deep vein thrombosis of the right distal femoral, popliteal, posterior tibial, and peroneal veins, as well as the left popliteal, gastrocnemius, and peroneal veins. Patient thromboprophylaxis was escalated to therapeutic dose anticoagulation and was then transferred to a medical floor 2 days later. On day 10 of admission, a CTPA performed in response to worsening pleuritic chest pain revealed subsegmental pulmonary embolus within the right lower lobe basilar pulmonary artery. Treatment strategy was thus switched 
to heparin therapeutic intravenous drip. Patient continued to improve and was subsequently discharged on oral anticoagulation with apixaban on day 17 of admission. Patient was screened for LAC and returned positive.

Patient 4 is a 36-year-old male with unremarkable past medical history, presented with fever and chills ongoing for 8 days. COVID-19 RT-PCR test was positive from day 1 of admission. CXR showed left mid-lung mild airspace opacities, with patient initially treated on a medical floor. Admission D-dimer was only slightly elevated, and patient was placed on standard DVT prophylaxis. On day 3 of admission patient was transferred to the ICU for worsening hypoxia and received tocilizumab. Ddimer continued to progressively increase and reached 6 times ULN on day 7; patient was thus placed on high intensity prophylaxis with enoxaparin $40 \mathrm{mg}$ BID. On day 11 of admission a CTPA obtained due to progressive hypoxia revealed large saddle embolus. Extension of embolus into the upper and lower lobar pulmonary arteries was evident, with resulting right heart strain. Patient received systemic alteplase followed by heparin drip for therapeutic anticoagulation. Patient improved and was transferred to a medical ward on day 14 of admission and eventually discharged home on oral anticoagulation on day 21 of admission. Patient was screened for LAC and returned positive.

Patient 5, a 51-year-old male, with history of hypertension transferred from outside hospital to the ICU at our institution on mechanical ventilation following severe COVID-19 ARDS. D-dimer was over 6 times ULN on transfer: Patient was directly placed on high intensity thromboprophylaxis with heparin 7500 SC TID and received tocilizumab on second day of admission. Patient's overall condition continued to worsen, developing acute kidney injury requiring continuous renal replacement therapy. CT chest with IV contrast obtained on day 11 to rule out collection as source of infection revealed bilateral PE, and patient was thus commenced on therapeutic IV heparin. D-dimer continued to be 6 times ULN throughout admission and up until day of event. Patient was screened for LAC and returned positive. His condition continued to deteriorate, developing bacteremia and cavitary lung disease with confirmed aspergillosis. Patient was treated with anti-fungal but progressed to invasive form with hemoptysis. Patient had a cardiac arrest and expired on day 76 of admission. All data related to the five patients is outlined in Table 1.

\section{Discussion and conclusions}

COVID-19 has been demonstrated to be widely implicated from a hematologic point of view. Pooled results from a meta-analysis of nine studies ( $n=1105$ patients) describing COVID-19 patient characteristics revealed that prothrombin time (PT) and D-dimer levels were significantly higher in patients with severe COVID-19 $\left(0.68,95 \% \mathrm{CI}=0.43-0.93, I^{2}=53.7 \%, 0.53,95 \% \mathrm{CI}=\right.$ $0.22-0.84, I^{2}=78.9 \%$, respectively) [4]. A similar metaanalysis that included 22 Chinese studies $(n=4889$ confirmed COVID-19 inpatients) found that severe patients had significantly higher D-dimer levels and prolonged PT compared with non-severe patients. Furthermore, non-survivors had significantly higher Ddimer levels, prolonged PT, and decreased platelet count compared with survivors [5]. Likewise, such findings have been observed and reported in different ethnicities and countries worldwide $[2,3]$.

Virus-mediated impacts on the immune system and its respective response, such as systemic inflammation and complement-system activation (cytokine storm), have been hypothesized to affect coagulation and hemostasis. Specific immune responses, such as an increase in white blood cells, may interact with and activate platelets, resulting in a clotting domino effect, and may possibly directly contribute to coagulopathy by forming plateletleukocyte aggregates. Moreover, considering the vital role played by the endothelium in maintaining hemostasis and inducing coagulation, and SARS-CoV-2's cell entry via ACE2 receptors (which are prevalent in endothelial cells), the virus may be directly implicated in the thrombotic events witnessed as a result of endothelial injury and inflammation (endothelialitis) [6]. In fact, recent evidence implicated COVID-19 as a vascular disease [7], with a new lung autopsy report showing unique features of severe endothelial injury associated with the presence of intracellular virus and disrupted cell membranes, as well widespread thrombosis with new vessel growth in COVID-19 patients [8]. Finally, the fact that most patients who were screened for LAC came back positive, is in-line with previous reports on the prevalence of LAC in COVID-19 patients [9]; a possible mechanism behind the increased clotting tendency. A recent prospective observational study confirms the frequent presence of single LAC positivity during acute phase of COVID-19 infection, but argues against a clear relation to thrombotic events. The study also notes that triple antiphospholipid positivity was very rare [10]. Nonetheless, many of these factors may potentially be involved in the observed increase of coagulation, particularly in severe infections. Therefore, markers of inflammation have been integrated in the overall suggested algorithms to both assess disease severity, and, potentially, the pending risk of clot formation.

At our institution, as in many others [11], we have been utilizing tocilizumab, a recombinant humanized anti-IL6 monoclonal antibody produced in mammalian 
Table 1 Patient baseline characteristics and parameters for inflammation and coagulopathy

\begin{tabular}{|c|c|c|c|c|c|}
\hline Variable & Patient 1 & Patient 2 & Patient 3 & Patient 4 & Patient 5 \\
\hline Age (yrs) & 51 & 79 & 31 & 36 & 51 \\
\hline BMI $\left(\mathrm{kg} / \mathrm{m}^{2}\right)$ & 26 & 33 & 30 & 30.7 & 22.6 \\
\hline Sex & Male & Male & Male & Male & Male \\
\hline Past Medical History & Diabetes & $\begin{array}{l}\text { Prostate Carcinoma } \\
\text { (remission) }\end{array}$ & Thalassemia, Asthma & None & Hypertension \\
\hline $\begin{array}{l}\text { Admission } \\
\text { Thromboprophylaxis } \\
\text { Regimen }\end{array}$ & $\begin{array}{l}\text { Heparin SC } 5000 \text { TID - } \\
\text { Heparin SC } 7500 \text { TID } \\
\text { on Day 2, based on D } \\
\text { Dimer over } 3\end{array}$ & Heparin SC 5000 TID & Enoxaparin $40 \mathrm{mg}$ daily & $\begin{array}{l}\text { Enoxaparin } 40 \text { mg daily, } \\
\text { increased to } 40 \text { mg BID } \\
\text { on day } 7\end{array}$ & Heparin 7500 TID \\
\hline Signs of thrombosis & $\begin{array}{l}\text { Day 3: } \\
\text { On observation, } \\
\text { ischemia of the first } 3 \\
\text { toes, no capillary refill }\end{array}$ & $\begin{array}{l}\text { Day 17: } \\
\text { No specific signs, } \\
\text { bilateral lower } \\
\text { extremity ultrasound } \\
\text { ordered based on } \\
\text { persistently high D } \\
\text { Dimer }\end{array}$ & $\begin{array}{l}\text { Day } 7 \text { : } \\
\text { Bilateral lower limb } \\
\text { pain }\end{array}$ & $\begin{array}{l}\text { Day 11: } \\
\text { No specific signs but } C T \\
\text { angiogram obtained for } \\
\text { persistent severe } \\
\text { hypoxemia and high D } \\
\text { Dimer }\end{array}$ & $\begin{array}{l}\text { Day 13: } \\
\text { No specific signs but } \\
\mathrm{CT} \text { chest with IV } \\
\text { contrast obtained to } \\
\text { rule out collection }\end{array}$ \\
\hline Imaging Requested & $\begin{array}{l}\text { CT Angiogram } \\
\text { (abdomen and pelvis } \\
\text { with lower extremity } \\
\text { runoff): } \\
\text { Floating thrombi } \\
\text { noted } 4 \mathrm{~cm} \text { infrarenal } \\
\text { abdominal aorta } \\
\text { compromising the } \\
\text { lumen with total } \\
\text { obliteration of the } \\
\text { right popliteal artery } \\
\text { and right anterior tibial } \\
\text { artery }\end{array}$ & $\begin{array}{l}\text { Bilateral lower } \\
\text { extremity Ultrasound: } \\
\text { The right posterior } \\
\text { tibial vein appears } \\
\text { dilated with visible } \\
\text { thrombus }\end{array}$ & $\begin{array}{l}\text { Bilateral lower } \\
\text { extremity Ultrasound: } \\
\text { Occlusive deep vein } \\
\text { thrombosis of the right } \\
\text { distal femoral, popliteal, } \\
\text { posterior tibial, and } \\
\text { peroneal veins, and the } \\
\text { left popliteal, } \\
\text { gastrocnemius and } \\
\text { peroneal veins }\end{array}$ & $\begin{array}{l}\text { CT Angiogram Chest: } \\
\text { Large saddle embolus, } \\
\text { extension of embolus } \\
\text { into the upper and } \\
\text { lower lobar pulmonary } \\
\text { arteries with right heart } \\
\text { strain }\end{array}$ & $\begin{array}{l}\text { CT Chest with IV } \\
\text { Contrast: } \\
\text { Multiple filling defects } \\
\text { noted bilaterally in the } \\
\text { pulmonary tree; } \\
\text { findings consistent with } \\
\text { pulmonary embolism. } \\
\text { Small filling defect seen } \\
\text { in the internal jugular } \\
\text { veins bilaterally, } \\
\text { consistent with } \\
\text { thrombi. }\end{array}$ \\
\hline Vascular Intervention & $\begin{array}{l}\text { 1.Percutaneous } \\
\text { mechanical } \\
\text { thrombectomy of the } \\
\text { infrarenal aorta } \\
\text { 2. Left lower extremity } \\
\text { intra-arterial } \\
\text { thrombolysis }\end{array}$ & None & None & None & None \\
\hline \multirow[t]{2}{*}{$\begin{array}{l}\text { Pharmacologic } \\
\text { Antithrombotic } \\
\text { Therapy for } \\
\text { Confirmed } \\
\text { thrombosis }\end{array}$} & $\begin{array}{l}\text { Heparin Drip per DVT/ } \\
\text { PE protocol (aPTT } \\
\text { target } 60-85 \text { ) }\end{array}$ & $\begin{array}{l}\text { Enoxaparin } 1 \mathrm{mg} / \mathrm{kg} \\
\text { BID from day } 17 \text { till } \\
\text { day } 29 \text { of admission } \\
\text { when patient } \\
\text { developed AKI and } \\
\text { switched to heparin } \\
\text { drip }\end{array}$ & $\begin{array}{l}\text { Enoxaparin } 1 \mathrm{mg} / \mathrm{kg} \\
\text { BID, switched to } \\
\text { heparin drip on day } 10 \\
\text { of admission }\end{array}$ & $\begin{array}{l}\text { Systemic alteplase } \\
\text { followed by heparin } \\
\text { DVT/PE protocol (aPTT } \\
\text { target 60-85) }\end{array}$ & $\begin{array}{l}\text { Heparin Drip per DVT/ } \\
\text { PE protocol (aPTT } \\
\text { target 60-85) }\end{array}$ \\
\hline & $\begin{array}{l}\text { Secondary ischemia of } \\
\text { bilateral lower } \\
\text { extremity, developing } \\
\text { left foot dry gangrene } \\
\text { requiring below-knee } \\
\text { amputation. Patient } \\
\text { improved and dis- } \\
\text { charged on oral } \\
\text { anticoagulation. }\end{array}$ & $\begin{array}{l}\text { Expired on day } 38 \text { of } \\
\text { admission, while on } \\
\text { heparin drip } \\
\text { therapeutic dose for } \\
\text { DVT/PE (aPTT target } \\
60-85) \text {, CRRT, and } \\
\text { mechanical } \\
\text { ventilation. } \\
\text { Potential PE }\end{array}$ & $\begin{array}{l}\text { Discharged on oral } \\
\text { anticoagulation with } \\
\text { apixaban on day } 17 \text { of } \\
\text { admission }\end{array}$ & $\begin{array}{l}\text { Patient improved and } \\
\text { was transferred to a } \\
\text { medical ward on day } \\
14 \text { of admission and } \\
\text { eventually discharged } \\
\text { home on oral } \\
\text { anticoagulation on day } \\
21 \text { of admission }\end{array}$ & $\begin{array}{l}\text { Developed bacteremia } \\
\text { and cavitary lung } \\
\text { disease with confirmed } \\
\text { aspergillosis, which } \\
\text { progressed to invasive } \\
\text { form with hemoptysis. } \\
\text { Patient had a cardiac } \\
\text { arrest and expired on } \\
\text { day } 76 \text { of admission } \\
\text { while on therapeutic IV } \\
\text { heparin and } \\
\text { mechanical ventilation. }\end{array}$ \\
\hline Tocilizumab & $\begin{array}{l}\text { Prior to admission at } \\
\text { OSH }\end{array}$ & Day 3 & Day 1 & Day 3 & Day 2 \\
\hline \multicolumn{6}{|l|}{ D-Dimer (mcg/mL) } \\
\hline Admission & Over 4 & Over 4 & 2.05 & 0.54 & Over 4 \\
\hline At time of event & Over 4 & Over 4 & Over 4 & Over 4 & Over 4 \\
\hline
\end{tabular}


Table 1 Patient baseline characteristics and parameters for inflammation and coagulopathy. (Continued)

\begin{tabular}{|c|c|c|c|c|c|}
\hline Variable & Patient 1 & Patient 2 & Patient 3 & Patient 4 & Patient 5 \\
\hline \multicolumn{6}{|l|}{ Platelets $\left(\times 10^{*} 9 / \mathrm{L}\right)$} \\
\hline Admission & 311 & 180 & 311 & 201 & 278 \\
\hline At time of event & 218 & 161 & 218 & 474 & 515 \\
\hline \multicolumn{6}{|c|}{ C-Reactive protein (mg/L) } \\
\hline Admission & 8 & 193 & 63.2 & 59.3 & 307.5 \\
\hline At time of event & 3.8 & 49 & 3.8 & 3.5 & 297.2 \\
\hline \multicolumn{6}{|l|}{ Fibrinogen (g/L) } \\
\hline Admission & 1.88 & NA & 6.57 & 4.53 & 7.06 \\
\hline At time of event & 1.4 & 5.01 & 3.29 & 2.53 & NA \\
\hline $\begin{array}{l}\text { Lupus } \\
\text { Anticoagulant }\end{array}$ & Negative & N/A & Positive & Positive & Positive \\
\hline
\end{tabular}

cells [12], as add-on therapy to the standard of care to treat patients with SARS-CoV-2 associated ARDS. The purpose is to dampen the hyperinflammatory response, and thus control the associated SARS-CoV-2 cytokines storm. All five patients that we report here received tocilizumab prior to the first thrombotic event. It is thus imperative to be aware that this drug could potentially mask the inflammatory markers (e.g. IL6, CRP, fibrinogen, and ferritin) [13-15], without reducing the risk of thrombotic events in this population, creating instead a façade of an improved prognostic outcome. The reduction however is fairly heterogenous in our small sample size, making larger studies necessary in order to map out and better understand the trend. In fact, a retrospective study in this context have demonstrated variable influences of tocilizumab on markers such as IL-6 and CRP [16]. Other retrospective cohort analyses however report results similar to our findings, with majority of patients

\section{Trend in Lab Values Relative to Tociluzimab Administration and Thromboemoblic Event in COVID-19 Patients}

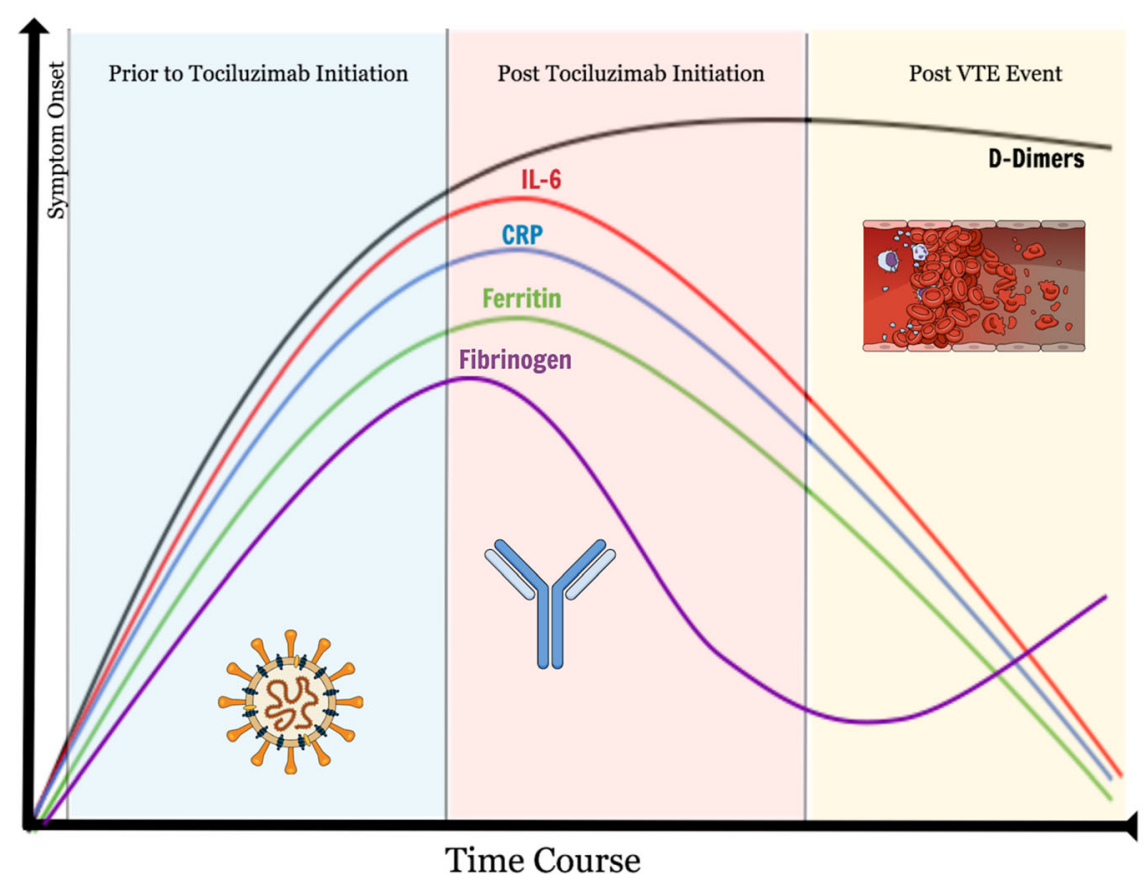

Fig. 1 General trend observed in lab values of COVID-19 patients prior to and post tocilizumab therapy and thrombotic events (not based on exact patient values) 
experiencing an elevation of D-dimers after Tocilizumab administration, while the inflammatory markers (ferritin, LDH and CRP) gradually decreased [17, 18]. Regardless, what can be asserted with more certainty is that the Ddimer levels remained prognostically reliable in these cases, as they were not affected by the drug and continued to be at the highest level until event occurrence (Fig. 1). Additionally, the fact that thrombotic events continued to be observed despite decrease in inflammatory markers and the proactive anticoagulative approach adopted, raises more questions about the coagulative mechanisms at play in COVID-19, and the appropriate management strategy. These findings remain observational nonetheless and open to bias and limitations. Randomized controlled trials will be necessary before any major change in policy.

In view of the increased thrombotic events documented globally [2-5], including at our institution, it is important to be aware of the effects of the current suggested COVID-19 regimens, such as tocilizumab, on biomarkers that may be integrated into the anticoagulation algorithms. Importantly, in the setting of tocilizumab therapy, traditional prognostic markers of worsening infection and inflammation, and thus potential risk of acute thrombosis, should be weighed carefully as they may not be reliable for prognosis.

\section{Acknowledgements}

None.

\section{Conflict of interest disclosure}

All Authors have no conflict of interest to disclose.

\section{Authors' contributions}

All authors contributed to the conception and writing of the manuscript.

\section{Funding}

None.

Availability of data and materials

Made available in Table 1, and via correspondence with BA.

\section{Ethics approval and consent to participate}

Not applicable as no patient identifiable data was included.

\section{Consent for publication}

Not applicable as no patient identifiable data was included, and two of the patients had expired.

\section{Author details}

'Department of Pharmacy Services, Cleveland Clinic Abu Dhabi, Al Maryah Island, Abu Dhabi, United Arab Emirates. ${ }^{2}$ Cleveland Clinic Lerner College of Medicine of Case Western Reserve University, Cleveland, OH, USA. ${ }^{3}$ School of Medicine, Royal College of Surgeons in Ireland-Bahrain, Al Sayh, Bahrain. ${ }^{4}$ Department of Clinical Pathology, Cleveland Clinic Abu Dhabi, Al Maryah Island, Abu Dhabi, United Arab Emirates. ${ }^{5}$ Critical Care Institute, Cleveland Clinic Abu Dhabi, Al Maryah Island, Abu Dhabi, United Arab Emirates.

${ }^{6}$ Normandy University, UNICAEN ED 497, Caen, France.
Received: 30 June 2020 Accepted: 26 August 2020

Published online: 09 September 2020

\section{References}

1. United Arab Emirates: WHO Coronavirus Disease (COVID-19) Dashboard (2020). Available at: https://covid19.who.int/region/emro/country/ae ().

2. Fogarty H, Townsend L, Ni Cheallaigh C, Bergin C, Martin-Loeches I, Browne P, Bacon CL, Gaule R, Gillett A, Byrne M, Ryan K. COVID-19 coagulopathy in Caucasian patients. Br J Haematol. 2020 Apr;24.

3. Helms J, Tacquard C, Severac F, et al. High risk of thrombosis in patients with severe SARS-CoV-2 infection: a multicenter prospective cohort study. Intensive Care Med 2020 4: 1-10. doi: https://doi.org/10.1007/s00134-02006062-x [Epub ahead of print].

4. Xiong $\mathrm{M}$, Liang $\mathrm{X}$, Wei YD. Changes in blood coagulation in patients with severe coronavirus disease 2019 (COVID-19): a meta-analysis. British Journal of $\mathrm{H}$.

5. Jin S, Jin $Y, X u$ B, Hong J, Yang $X$. Prevalence and impact of coagulation dysfunction in COVID-19 in China: a meta-analysis. Thromb Haemost. 2020 Jul;17.

6. Atallah B, Mallah SI, AlMahmeed W. Anticoagulation in COVID-19. European Heart Journal -Cardiovascular Pharmacotherapy. April 2020. https://doi.org/ 10.1093/ehjcvp/pvaa036.

7. Varga Z, Flammer AJ, Steiger P, Haberecker M, Andermatt R, Zinkernagel AS, Mehra MR, Schuepbach RA, Ruschitzka F, Moch H. Endothelial cell infection and endotheliitis in COVID-19. Lancet. 2020 May 2;395(10234):1417-8.

8. Pulmonary Vascular Endothelialitis, Thrombosis, and Angiogenesis in Covid19 | NEJM. (2020). New England Journal of Medicine, [online] p. Available at: https://www.nejm.org/doi/full/10.1056/NEJMoa2015432 [.

9. Bowles L, Platton S, Yartey N, Dave M, Lee K, Hart DP, MacDonald V, Green L, Sivapalaratnam S, Pasi KJ, MacCallum P. Lupus anticoagulant and abnormal coagulation tests in patients with Covid-19. N Engl J Med. 2020 May.

10. Kotch C, Barrett D, Teachey DT. Tocilizumab for the treatment of chimeric antigen receptor $\mathrm{T}$ cell-induced cytokine release syndrome. Expert Rev Clin Immunol. 2019 Aug;15(8):813-22.

11. Guaraldi G, Meschiari M, Cozzi-Lepri A, Milic J, Tonelli R, Menozzi M, Franceschini E, Cuomo G, Orlando G, Borghi V, Santoro A. Tocilizumab in patients with severe COVID-19: a retrospective cohort study. The Lancet Rheumatology. 2020 Jun;24.

12. Isaacs JD, Harari O, Kobold U, et al. Effect of tocilizumab on haematological markers implicates interleukin-6 signalling in the anaemia of rheumatoid arthritis. Arthritis Res Ther. 2013;15(6):R204.

13. Actemra (tocilizumab) [package insert]. South San Francisco, CA: Genentech, Inc; 2019. Accessed April 27, 2020. https://www.accessdata.fda.gov/ drugsatfda docs/label/2017/125276s114/bl.pdf.

14. Imamura $\mathrm{H}$, Momohara S, Yano K1, et al. Tocilizumab treatment in patients with rheumatoid arthritis is associated with reduced fibrinogen levels and increased blood loss after total knee arthroplasty. Mod Rheumatol 2018; 28(6):976-980. doi: https://doi.org/10.1080/14397595.2018.1428041. Epub $2018 \operatorname{Jan} 30$

15. Devreese KM, Linskens EA, Benoit D, Peperstraete H. Antiphospholipid antibodies in patients with COVID-19: a relevant observation? J Thromb Haemost. $2020 \mathrm{Jul} ; 3$.

16. Chan KH, Patel B, Podel B, Szabela ME, Shaaban HS, Guron G, Slim 」. Tocilizumab and Thromboembolism in COVID-19: A Retrospective Hospitalbased Cohort Analysis.

17. Price CC, Altice FL, Shyr Y, Koff A, Pischel L, Goshua G, Azar MM, Mcmanus D, Chen SC, Gleeson SE, Britto CJ. Tocilizumab treatment for cytokine release syndrome in hospitalized COVID-19 patients: survival and clinical outcomes. Chest. 2020 Jun;15.

18. Luo P, Liu Y, Qiu L, Liu X, Liu D, Li J. Tocilizumab treatment in COVID-19: a single center experience. J Med Virol. 2020 Jul:92(7):814-8.

\section{Publisher's Note}

Springer Nature remains neutral with regard to jurisdictional claims in published maps and institutional affiliations. 